\title{
Predation of an American fruit-eating bat (Artibeus sp.) by an Amazon tree boa (Corallus hortulanus) in the northern Brazilian Amazon
}

\author{
William Douglas de CARVALHO ${ }^{1 *}$, Saulo Meneses SILVESTRE ${ }^{1}$, Karen MUSTIN², \\ Renato Richard HILÁRIO ${ }^{1}$, José Júlio de TOLEDO ${ }^{1}$ \\ Universidade Federal do Amapá - UNIFAP, Departamento de Meio Ambiente e Desenvolvimento, Laboratório de Ecologia, Rododovia Juscelino Kubitschek, s/n, \\ Macapá-AP, 68903-419, Brazil \\ 2 University of Aberdeen, Institute of Biological and Environmental Sciences, Zoology Building, Tillydrone Avenue, Aberdeen, AB24 2 TE, UK \\ * Corresponding author: wilruoca@hotmail.com
}

\section{ABSTRACT}

We report an observation of predation by an Amazon tree boa, Corallus hortulanus, on an American fruit-eating bat, Artibeus sp., in an area of seasonal forest close to a small stream in the northern Brazilian Amazon. While bats appear to be one of the main food items of $C$. hortulanus, our observation is only the fourth such event to be recorded in the Brazilian Amazon. The Artibeus sp. individual was observed making distress (agony) calls continuously over a period of three hours, much longer than recorded on previous observations. Records of this type are important to further our knowledge on bat predators, and the defensive behavior of bats.

KEYWORDS: Amazonian savanna; defense behavior; PPBio; Lavrados of Roraima

\section{Predação de um morcego frugívoro (Artibeus sp.) por uma suaçubóia (Corallus hortulanus) no norte da Amazônia brasileira}

\section{RESUMO}

Nós relatamos uma observação de predação por uma serpente Corallus hortulanus sobre um morcego do gênero Artibeus em uma área de floresta estacional perto de um córrego, no norte da Amazônia brasileira. Enquanto os morcegos parecem ser um dos principais itens alimentares de C. hortulanus, a nossa observação representa somente o quarto relato para a Amazônia brasileira. O indivíduo de Artibeus sp. foi observado vocalizando com chamados de distress (agonia) durante um período de três horas, o que representa uma duração muito maior do que o reportado em registros anteriores. Registros deste tipo são extremamente importantes para aumentar o nosso conhecimento sobre os predadores de morcegos e sobre o comportamento de defesa dos morcegos.

PALAVRAS-CHAVE: savanas amazônicas; comportamento de defesa; PPBio; Lavrados de Roraima

American fruit-eating bats of the genus Artibeus (Phyllostomidae) are among the most common bat species in Neotropical forests, and are widely distributed throughout the Americas (Gardner 2008). They are frugivores, but also consume nectar, pollen, leaves, and even insects (Gardner 2008). These bats form colonies from just a few to hundreds of individuals, that usually shelter during the day in tree hollows and other natural cavities (Guimarães et al. 2014), in foliage (Garbino and Tavares 2018), or under the rooves of houses or inside abandoned buildings in urban areas (Biavatti et al. 2015). During the night, after acquiring their necessary food, Artibeus spp. rest on feeding perches away from their daytime roosts (Passos and Graciolli 2004). At least four species of natural predators are known to prey on Artibeus spp., either inside or outside of refuges (see review by Costa et al. 2016). However, there are only five records of predation on Artibeus spp. in Brazil, two of which were by the Amazon tree boa, Corallus hortulanus (Boidae), one by the striped owl, Asio clamator, and two by the American barn owl, Tyto furcata (Barnett et al. 2007; Costa et al. 2016).

The Amazon tree boa is the most widespread species of Corallus in South America (Henderson 1997). These mediumsized, nocturnal and arboreal snakes are usually found near 
water bodies (Henderson et al. 2013), feed mainly on birds and small mammals, and, as in all Boidae species, kill their prey through constriction (Henderson and Pauers 2012; Gonzales et al. 2016). After birds, which account for approximately $40 \%$ of the diet, bats are the second most frequent food item of $C$. hortulanus (approximately 16\%) (Henderson and Pauers 2012). Although $C$. hortulanus is a relatively abundant species, observation of predation events by this snake are rare (Silva and Henderson 2012), despite it being responsible for almost one third (29\%) of recorded predation events of bats by snakes in Brazil (Hopkins and Hopkins 1982; Barnett et al. 2007; Costa et al. 2016). Coralus hortulanus has already been recorded predating on Artibeus sp. in Brazil (Barnett et al. 2007; Costa et al. 2016), as well as on Myotis sp., Carollia perspicillata (Esbérard and Vrcibradic 2007), and Platyrrhinus lineatus (Costa et al. 2016).

While being considered to be one of the key drivers of survival in wild populations, predation is not easily observable (Stanford 2002). Consequently, current knowledge of predator-prey relationships has been largely built upon studies of predator diets (e.g. Escarlate-Tavares and Pessôa 2005), and the collection of opportunistic observations of predation in the wild (e.g. Carvalho et al. 2016; Hilário et al. 2017; SerraGonçalves et al. 2017). Knowledge is particularly scarce on the interaction of bats as prey and their predators in Brazil (Costa et al. 2016), mainly because of the difficulty in making direct observations of predation events (Silva and Henderson 2012).
The predation event reported here represents only the fourth observation of predation on bats by Corallus hortulanus in the Brazilian Amazon. Previous events were recorded in Campina Reserve (Hopkins and Hopkins 1982), and Jaú National Park (two events) (Martins and Oliveira 1998; Barnet et al. 2007), in Amazonas state. We also discuss defense behavior of bats, and the importance of bats in the diet of $C$. hortulanus.

Our observation was made during a field survey of bats in the Serra da Lua sampling modules of Programa PPBio (https://ppbio.inpa.gov.br), located in the municipality of Bomfim, Roraima State, northern Brazil (244'19.32"N, $60^{\circ} 17^{\prime} 60.00^{\prime \prime W)}$. For more details on the Serra da Lua PPBio modules, see Souza (2014). The area is part of the 'Lavrados de Roraima', one of the largest complexes of Amazonian savannas (Carvalho and Mustin 2017). The transect where the observation was made is located inside a patch of seasonal forest, in a seasonally flooded area near a small stream. On $20^{\text {th }}$ July 2017, shortly after 00:00, an American fruit-eating bat was heard vocalizing near the trail where mist-nets had been set at ground level. The sound that the bat emitted was a distress call, and we thought the bat had been caught in the nets that had been recently closed for the night. When we got close to the nets, we noticed that the distress call came from the canopy. After illuminating the site with torchlight and using binoculars and a camera with 50x zoom, we were able to observe a snake, approximately $12 \mathrm{~m}$ above ground level, in a tree, constricting the bat (Figure 1). Based on

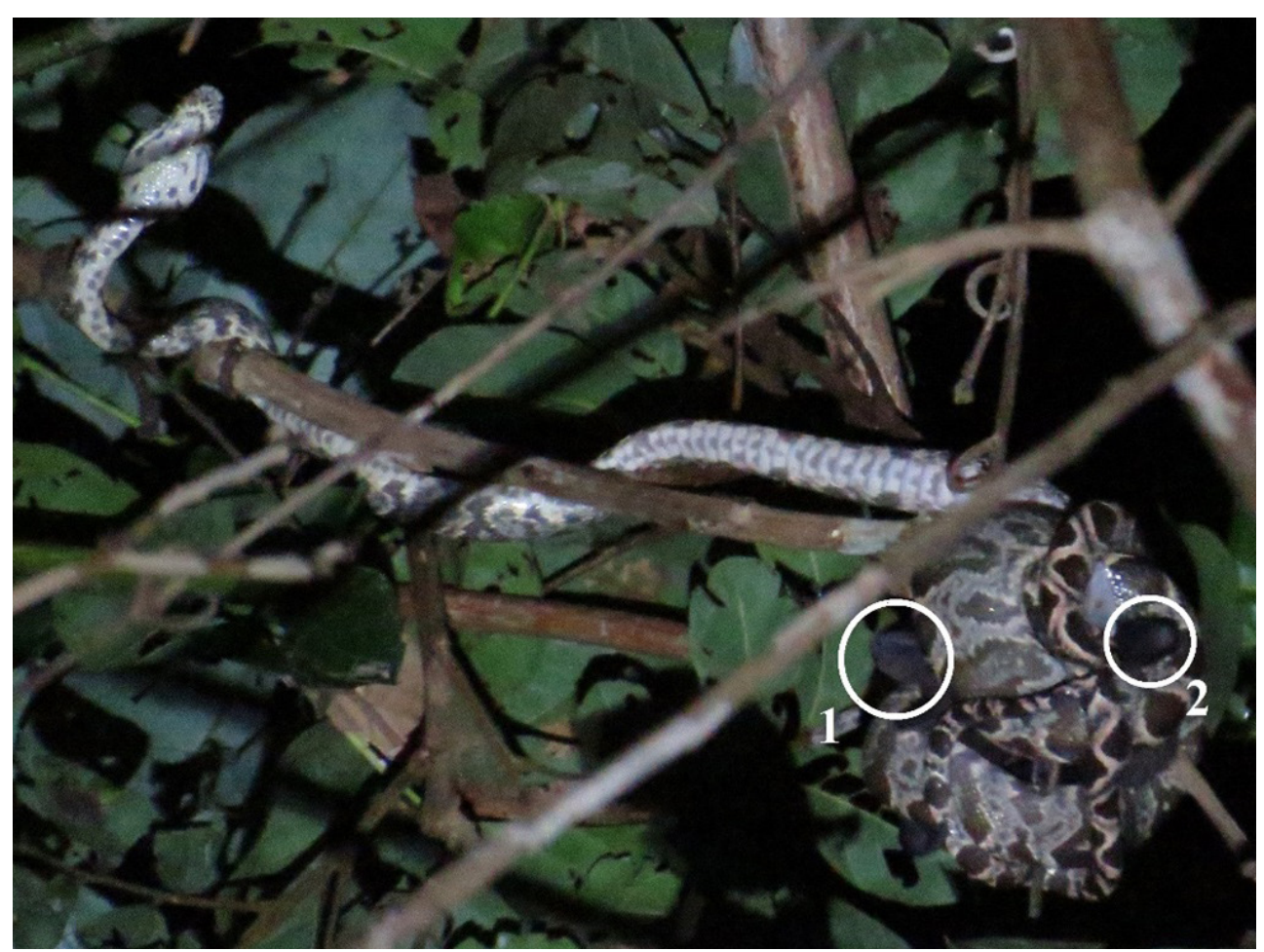

Figure 1. Individual of American fruit-eating bat (Artibeus sp.) being predated by an Amazon tree boa (Corallus hortulanus). 1 - Left elbow joint; 2 - Left wrist joint. This figure is in color in the electronic version. 
the type of distress call being emitted (see video at http:// www.scielo.br/scielo.php?script $=$ sci arttext\&pid $=$ S004459672019000100024\&lng=en\&nrm=iso\&tlng=en), the size of the bat, and a brief visualization of the bat's head, with conspicuous white stripes, we were able to identify it as being an Artibeus sp. Subsequently, from photos and with the aid of a reptile specialist (Dr. Hélio Ricardo da Silva), we were able to identify the snake as $C$. hortulanus. We observed the snake and the bat for at least one hour, but the individual of Artibeus sp. kept vocalizing for at least another two hours (until approximately 03:00 AM). At dawn ( 07:00 AM), we no longer observed the snake or the bat in the place where the predation event took place.

Two previous records of bat predation by $C$. hortulanus have been registered in Jaú National Park, near the Jaú River (Martins and Oliveira 1998; Barnett et al. 2007). Of these records, only Barnett et al. (2007) identified the bat to genus level as an Artibeus sp., which was predated at its roost. Our observed predation event also took place close to a water body, a habitat more conducive to the occurrence of $C$. hortulanus (Henderson 1997; Smith and Acevedo 1997; Henderson et al. 2013). As we had the opportunity to observe the predation event immediately after the capture of the bat, we were able to observe the bat's defense behavior, characterized by constant and brief contractions of the body, and constant vocalization (distress calls). The distress call is a behavior that occurs mainly when bats are handled by humans (August 1985; Mass et al. 2010), and may act as an alarm to conspecifics that are nearby, and/or may attract them to assist in the disentangling of the prey from the predator (August 1979; August 1985; Conover 1994). However, in this case we did not observe other bats approaching the individual making the distress calls, even though our capture rates of Artibeus spp. (Artibeus lituratus, Artibeus obscurus and Artibeus planirostris) were considered high in the site where the predation occurred $(31.8 \%$ of bats captured, $n=22)$. We also did not observe attraction of conspecifics when the Artibeus spp. were trapped in the mist net or while being handled. It is noteworthy that we observed the bat emitting distress calls for at least three hours, much longer than recorded in previous observations ( -30 min, Hopkins and Hopkins 1982). Based on the long time taken to kill the bat, we hypothesize that the snake may have still been a juvenile and not yet able to kill its prey rapidly, as juvenile snakes are slower than adults (Pough 1977). However, it was not possible to estimate the age of the snake, since the specimen was not collected.

Combined with previous records, these observations indicate that bats may be important in the diet of Boidae, particularly for $C$. hortulanus. This snake species tends to live and forage in the tree canopy, probably being more effective in exploring the vertical stratum of the forest (Pizzato et al. 2009), and, as such, it is not surprising that both birds and bats are important diet components, as they tend to perch or forage in canopy vegetation (Passos and Graciolli 2004; Garbino and Tavares 2018). In addition, Stenodermatinae bats, such as Artibeus sp., are known to use foliage as shelters (e.g. tents) (Garbino and Tavares 2018), and the use of these places as roosts may be a key factor leading to predation of these animals by $C$. hortulanus. Records of predation as reported here are important contributions to the knowledge of predator diets and the defense behaviors of bats (Costa et al. 2016).

\section{ACKNOWLEDGMENTS}

William Douglas de Carvalho and Saulo Menezes Silvestre are supported, respectively, by post-doctoral (PNPD/CAPES) and doctoral scholarships of the Coordenação de Aperfeiçoamento de Pessoal de Nível Superior (CAPES), Brazil. Karen Mustin is supported by a Marie Skłodowska-Curie Individual Fellowship (EU). We thank IBAMA for authorization to conduct research in the ANF (IBAMA/SISBIO permit 58887-1). This work was supported by the Conselho Nacional de Desenvolvimento Científico e Tecnológico - CNPq (grant number CNPQ/ Universal 459735/2014-4). We thank Hélio Ricardo da Silva (Universidade Federal Rural do Rio de Janeiro - UFRRJ) for the snake identification.

\section{REFERENCES}

August, P.V. 1979. Distress calls in Artibeus jamaicensis: ecology and evolutionary implications. In: Eisenberg, J.F. (Ed.). Vertebrate ecology in the northern neotropics. Smithsonian Institution Press, Washington, D.C, p.151-159.

August, P.V. 1985. Acoustical properties of the distress calls of Artibeus jamaicensis and Phyllostomus hastatus (Chiroptera: Phyllostomidae). The Southestern Naturalist, 30: 371-375.

Barnett, A.; Schiel, V.; Deveny, A. 2007. Corallus hortulanus (Amazon tree boa): bat predation in Jaú National Park. Herpetological Bulletin, 100: 35-38.

Biavatti, T.; Costa, L.M.; Esbérard, C.E.L. 2015. Morcegos (mammalia, chiroptera) em refúgios diurnos artificiais na região sudeste do Brasil. Mastozoología Neotropical, 22: 239-253.

Carvalho, W.D.; Norris, D.; Michalski, F. 2016. Opportunistic predation of a Common Scale-backed Antbird (Willisornis poecilinotus) by a Goliath bird-eating spider (Theraphosa blondi) in the Eastern Brazilian Amazon. Studies on Neotropical Fauna and Environment, 51: 239-241.

Carvalho, W.D.; Mustin, K. 2017. The little known, highly threatened and under-protected Amazonian Savannas. Nature Ecology \& Evolution, 1: 0100.

Conover M.R. 1994. Stimuli eliciting distress calls in adult passerines and response of predators and birds to their broadcast. Behaviour, 131: 19-37.

Costa, L.M.; Tabosa, L.O.; Luz, J.L.; Carvalho, W.D. 2016. Predadores naturais de morcegos no Brasil. Boletim da Sociedade Brasileira de Mastozoologia, 77: 131-142.

Esbérard, C.E.L.; Vrcibradic, D. 2007. Snakes preying on bats: new records from Brazil and a review of recorded cases in the Neotropical Region. Revista Brasileira de Zoologia, 24: 848-853. 
Escarlate-Tavares, F.; Pessôa, L.M. 2005. Bats (Chiroptera, Mammalia) in barn owl (Tyto alba) pellets in northern Pantanal, Mato Grosso, Brazil. Mastozoología Neotropical, 12: 61-67.

Garbino, G.S.T.; Tavares, V.C. 2018. Roosting ecology of Stenodermatinae bats (Phyllostomidae): evolution of foliage roosting and correlated phenotypes. Mammal Review, 48: 75-89.

Gardner, A.L. 2008. Mammals of South America, volume 1: marsupials, xenarthrans, shrews, and bats. University of Chicago Press, Chicago. 669p.

Gonzalez, R.C.; Silva-Soares, T.; Crozariol, M.A.; Citeli, N.K.; Brito, G.R.R. 2016. Corallus hortulanus (Linnaeus, 1758) (Squamata: Serpentes: Boidae) diet: predation events on two Passeriformes at the Atlantic Rainforest, southeastern Brazil. Herpetology Notes, 9: 87-89.

Guimarães, M.M.; Ferreira, R. L. 2014. Morcegos cavernícolas do Brasil: Novos registros e dasafios para conservação. Revista Brasileira de Espeleologia, 2: 1-33.

Henderson, R.W.; Pauers, M.J. 2012. On the diets of Neotropical treeboas (Squamata: Boidae: Corallus). South American Journal of Herpetology, 7: 172-180.

Henderson, R.W.; Pauers, M.J.; Colston, T.J. 2013. On the congruence of morphology, trophic ecology, and phylogeny in Neotropical treeboas (Squamata: Boidae: Corallus). Biological Journal of the Linnean Society, 109: 466-475.

Henderson, R.W. 1997. A taxonomic review of the Corallus hortulanus complex of Neotropical tree boas. Caribbean Journal of Science, 33: 198-221.

Hilário, R.R.; Silva, C.; Santos Jr, L.S.; Rocha, P.A.D.; Beltrão-Mendes, R.; Ruiz-Esparza, J.; Ferrari, S.F. 2017. Predation of birds in mist nets by callitrichids (Primates): how to prevent similar events. Studies on Neotropical Fauna and Environment, 52: 168-172.

Hopkins, H.C.; Hopkins, M.J. 1982. Predation by a snake of a flower-visiting bat at Parkia nitida (Leguminosae: Mimosoideae). Brittonia, 34: 225-227.

Martins, M.; Oliveira, M.E. 1998. Natural history of snakes in forests of Manaus region, Central Amazonia, Brazil. Herpetological Natural History, 6: 78-150.
Mass, A.C.S.; Nogueira, M.R.; Peracchi, A.L. 2010. Propriedades acústicas dos chamados de "distress" emitidos por Artibeus lituratus (Olfers, 1818) e Artibeus obscurus (Schinz, 1821) durante manipulação em campo. Chiroptera Neotropical (Suplemento), 16: $124-126$.

Passos, F.C.; Graciolli, G. 2004. Observaçôes da dieta de Artibeus lituratus (Olfers) (Chiroptera, Phyllostomidae) em duas áreas do sul do Brasil. Revista Brasileira de Zoologia, 21: 487-489.

Pizzatto, L.; Marques, O.A.V.; Facure, K. 2009. Food habits of Brazilian boid snakes: overview and new data, with special reference to Corallus hortulanus. Amphibia-Reptilia, 30: 533-544.

Pough, F.H. 1977. Ontogenetic change in blood oxygen capacity and maximum activity in Garter Snakes (Thamnophis sirtalis). Journal of Comparative Physiology - B, 116: 337-345.

Silva, P.C.; Henderson, R.W. 2012. Observations on foraging behavior in the Amazon treeboa (Corallus hortulanus). Herpetology Notes, 5: 531-532.

Serra-Gonçalves, C.; López-Baucells, A.; Rocha, R. 2017. Opportunistic predation of a silky short-tailed bat (Carollia brevicauda) by a tawny-bellied screech-owl (Megascops watsonii), with a compilation of predation events upon bats entangled in mist-nets. Barbastella, 10:1-6.

Souza, S.A. 2014. Efeito do plantio de Acacia mangium Willd. (Fabaceae) sobre a riqueza e diversidade arbórea em áreas de savana na amazônia setentrional. Master's dissertation, Programa de Pós-graduação em Recursos Naturais (PRONAT), Universidade Federal de Roraima, Boa Vista, Roraima, 64p.

Stanford, C.B. 2002. Avoiding predators: expectations and evidence in primate antipredator behavior. International Journal of Primatology, 23: 741-757.

RECEIVED: $25 / 05 / 2018$

ACCEPTED: $13 / 09 / 2018$

ASSOCIATE EDITOR: Paulo Bobrowiec 